\title{
Recommended Storage Temperature
}

National Cancer Institute

\section{Source}

National Cancer Institute. Recommended Storage Temperature. NCI Thesaurus. Code C101707.

The recommended storage temperature for a device. 